\title{
Teaching Teachers from Standards to Lessons
}

\author{
Coggin Heeringa
}

Crossroads at Big Creek, Inc. - Sturgeon Bay, WI

\begin{abstract}
Funds from Wisconsin Space Grant Consortium were used to provide scholarship stipends to upper elementary and middle school teachers, enabling them to take a continuing education class through the University of Wisconsin-Green Bay Education Outreach Program and/or participate in workshops sponsored by Crossroads at Big Creek. The objective of the class and workshops was to help teachers gain content knowledge and develop lessons aligned with the proposed Next Generation Science Standards.
\end{abstract}

\section{Background}

Crossroads at Big Creek is a 200-acre environmental preserve located in Sturgeon Bay, Wisconsin. Crossroads offers experience-based programs in science, history and the environment for learners of all ages. The Collins Learning Center is used for educational programs. The Astronomy Campus boasts a classroom building, and observatory, and a StarGarden-- an outdoor area dedicated to night sky viewing. The Door Peninsula Astronomical Society (DPAS) meets at Crossroads and often assists with or sponsors outreach activities.

Crossroads hosts about 100 school fields trips each year, but in addition to providing programs for Door County schools, Crossroads collaborates with the University of Wisconsin-Green Bay to offer teacher education, offering three to four one-credit classes annually to teachers from districts through northeast Wisconsin. At the same time, the 2014 Wisconsin Space Grant proposals were due, the Wisconsin Department of Instruction (DPI) announced that the Next Generation Science Standards would soon be available. Next Generation Standards are "rigorous, internationally benchmarked standards for K-12 science education... designed to identify science and engineering practices and content that all students should master in order to be fully prepared for college, careers and citizenship." The release seemed a wonderful opportunity to introduce teachers to these new documents and help them develop lessons to bring the concepts alive in their classrooms. The University of Wisconsin-Green Bay Education Outreach coordinator was enthusiastic about the idea and encouraged Crossroads to submit a course syllabus, which was approved as a summer school offering for 2013.

The Door Peninsula Astronomical Society was planning an outreach event called "Celebrate the Sun" in the spring. Also, the press began announcing the approach of yet another "the comet of the century" which would circle the Sun around Thanksgiving. The workshops were combined with public outreach events. Teachers gain experience and confidence by staffing the learning stations during outreach events. 
Crossroads at Big Creek was awarded a grant providing partial funding to offer scholarship stipends for teachers who participate in the class and workshop. Offering stipends greatly improved the recruitment of teachers. In fact, generous stipends often attract teachers with little previous training or even interest in astronomy. Reaching these teachers is, perhaps, the most important outcome of the project.

\section{Project}

Crossroads conducted a workshop pertaining to the Sun in collaboration with the Door Peninsula Astronomical Society and hosted a teacher workshop and several school field trips prior to the approach of Comet ISON. The University of Wisconsin-Green Bay offered the "Astronomyfrom Standards to Lessons" class in June of 2013 with eleven teachers enrolled in the class for credit and one teacher taking the non-credit option. Crossroads provided instruction and facilities use. Each participant was given a binder containing the copies of the standards pertaining to space education. The intent was that each teacher would select a standard and prepare student-ready activities which the class would share.

The first topic discussed was the electromagnetic spectrum. To the middle school science specialists (most of whom were biology majors) the Next Generation Science Standards were nothing short of an epiphany. Comments such as "I had no idea." ... "How can we teach this if we've never heard of it?" ... "I thought the spectrum was ROY G BIV". As it turned out, the class spent the whole class on the electromagnetic spectrum, finding amazing websites and applications which would engage their students. As one teacher pointed out, "It's everything kids care about: preparing food, television, radio, social media, and animal behavior! If this doesn't get them interested in STEM, nothing will!"

The Comet ISON Workshop was a success, in spite of the fact that the comet broke up and disappeared while rounding the Sun, which occurred before the scheduled comet viewing session. Teachers learned a great deal by presenting hands-on activities and by interacting with amateur astronomers during public outreach events, and also improved DPAS events because they could relate to students.

The Next Generation Science Standards were not adopted by the state of Wisconsin, and it seems unlikely that the state will adopt them in the foreseeable future. Consequently, the stated goal of preparing teachers to use the Next Gen standards was not met. Apparently, now districts are responsible for creating science curricula, so introducing teachers to basic concepts was probably even more important.

\section{Conclusions}

Based on our experiences in 2013, we have concluded:

1. Offering scholarship/stipends to teachers for participation in classes and workshops greatly increases enrollments, and that continuing education classes which offer credit are more desirable to most teachers, especially those who have been teaching for some time. 
2. Many "science specialists" in elementary and middle schools have not been exposed to many of the concepts upon which the Next Generation Science Standards are based.

3. When teachers present activities in public outreach settings, they are more likely to use them in their own classrooms.

4. A lot of teaching is showmanship. When teachers have access to equipment and props, they are more likely to go beyond the written word and consequently, their students are more likely to respond.

\section{Evaluation}

Unfortunately, because the class was offered in summer, Crossroads had no way of determining whether or not the participating teachers used the lessons they created once they were back in their own classrooms. We suspect and hope that the lessons have become a part of the curricula of the six districts that were represented in the class.

\section{Acknowledgement}

This project has been made possible with a grant from the Wisconsin Space Grant Consortium and with assistance from University of Wisconsin-Green Bay Education Outreach and the Door Peninsula Astronomical Society. 